\title{
PERHITUNGAN KAPASITAS JALAN DAN PERKERASAN LENTUR Study Kasus : Ruas Jalan Pasir Hayam - Cibeber Kecamatan Cibeber Kabupaten Cianjur (Km. Bdg 75 - Km. Bdg 82)
}

\author{
Oleh : \\ Yudi Sekaryadi, Ir,. Mt. ${ }^{2}$ \\ Seprala Catolin Sinurat. $\mathrm{S}^{1}$ \\ Program Studi Teknik Sipil Universitas Suryakancana ${ }^{1}$ \\ Universitas Suryakancana ${ }^{2}$
}

\begin{abstract}
ABSTRAK
Kapasitas adalah jumlah maksimum kendaraan atau orang yang dapat melintasi suatu titik pada lajur jalan pada periode waktu tertentu dalam kondisi jalan tertentu atau merupakan arus maksimum yang dapat dilewatkan pada suatu ruas jalan.Dari perhitungan kapasitas Ruas jalan Pasir Hayam Cibeber Kecamatan Cibeber KabupatenCianjur (Km. Bdg 75 - Km. Bdg 82) tersebut didapat nilai $\mathrm{C}=2912,76$ dan nilai $\mathrm{Co}=2900$ maka tidak diperlukan pelebaran jalan karena kapsitas masih memenuhi.Ruas jalan Pasir Hayam - Cibeber Kecamatan Cibeber KabupatenCianjur (Km. Bdg 75 - Km. Bdg 82) dilakukan pelapisan tambahan dikarenakan jalan kurang baik, dari perhitungan pelapisan jalan dilakukan dengan metode perkerasan lentur dengan tinggi $13 \mathrm{~cm}$ dengan Rencana Anggaran Biaya (RAB) sebesar Rp 12.496.385.293
\end{abstract}

Kata Kunci : Ruas Jalan, kapasitas jalan, perencanaan lentur

\section{BAB I PENDAHULUAN}

\subsection{Latar Balakang}

Jalan merupakan suatu konstruksi yang berfungsi sebagai prasarana perhubungan darat yang memegang peranan penting dalam kehidupan manusia. Dengan adanya jalan yang memadai dapat memperlancar distribusi barang dan jasa sehingga kebutuhan pemakai jalan dapat terpenuhi.

Meningkatnya kemacetan pada jalan perkotaan maupun jalan luar kota yang diakibatkan bertambahnya kepemilikan kendaraan, terbatasnya sumberdaya untuk pembangunan jalan raya, dan belum optimalnya pengoperasian fasilitas lalu lintas yang ada, merupakan persoalan utama di banyak negara. Seperti diketahui bahwa sekarang ini banyak sekali alat transportasi yang dapat digunakan, namun alat transportasi daratlah yang banyak dan sering digunakan oleh pemakainya. Sekarang ini pengaturan lalu lintas tidak hanya terbatas pada arus lalu lintas saja, tetapi juga dirasakan perlu diketahui hubungan dan akibat dari adanya fasilitas-fasilitas transportasi pada keadaan lingkungan sekitarmya, sehingga akan sesuai dengan apa yang diingini.

Menajemen lalu lintas harus dilihat sebagai bagian yang tak terpisahkan dari teknik transportasi dimana jaringan jalan raya merupakan suatu bagian dari sistem transportasi secara keseluruhan. Keadaan jalan yang macet bukanlah hal yang baru dialami di kota-kota besar khususnya di Indonesia. Hal ini diutamakan karena bertambahnya keinginan masyarakat untuk menggunakan kendaraan-kendaraan bermotor pribadi untuk memenuhi aktivitas kehidupannya tanpa melihat jauh dampak yang ditimbulkan. Dengan selalu bertambahnya pengguna jalan, terutama pada jam-jam tertentu sehigga menuntut adanya peningkatan kualitas dan kuantitas suatu jalan, untuk 2 itulah perlu adanya penelitian mengenai kapasitas jalan dan geometric jalan yang ada sehingga dapat dievaluasi dan dianalisa untuk mengantisipasi perkembangan jumlah kendaraan 


\subsection{Rumusan Masalah}

Adapun rumusan masalah dalam penelitian ini, berdasarkan latar belakang tersebut diatasadalahsebagai berikut :

1. Bagaimana merencanakan bentuk desain alternative perkerasan jalan?

2. Bagaimana cara perhitungan kapasitas jalan?

3. Perhitungan RAB perkerasan jalan ?

\subsection{Tujuan}

Adapun tujuan penelitian dalam tugas akhir ini adalah sebagai berikut :

1. 1. Menghitung kapasitas jalan Jalan Pasir Hayam KM BDG $75 \pm 0.00-$ Cibeber KM BDG $82 \pm 0.00$ menggunakan MKJI

2. Mengevaluasi faktor - faktor yang mempengaruhi tingkat pelayanan ruas jalan yang terjadi pada ruas Jalan Pasir Hayam KM BDG $75 \pm 0.00-$ Cibeber KM BDG $82 \pm 0.00$

3. Perhitungan perkerasan lentur pada Jalan Raya Pasir Hayam KM BDG 75 \pm 0.00 - Cibeber KM BDG $82 \pm 0.00$ menggunakan SNI 1732-1989-F

4. Mengetahui biaya anggaran pembuatan jalan Raya Pasir Hayam KM BDG $75 \pm 0.00$ - Cibeber KM BDG $82 \pm 0.00$

\subsection{Ruang Lingkup Penelitian}

Karena keterbatasan peneliti dalam waktu dan tenaga untuk memecahkan suatu permasalahan maka peneliti membatasi masalah yang ada. Maka ruang lingkup penelitian adalah sebagai berikut:

1. Evaluasi kapasitas jalan menggunakan MKJI.

2. Kontruksi jalan yang direncakan dianggap merupakan overlay atau overload.

3. Metode perencanaan mengacu pada metode Analisa Komponen SNI 1732-1989-F

4. Umur rencana 10 tahun.

1.5 Manfaat Penelitian
Manfaat yang di peroleh dari kajian ini diharapkan akan mendapatkan masukan yang didapat melalui survey seperti volume lalu lintas, hambatan samping, kapasitas jalan yang kemudian diolah kembali data tersebut dan nantinya akan digunakan dalam perencanaan transportas luar kota pada umumnya dan khususnya perencanaan jalan luar kota, sehingga dapat meningkatkan kinerja ruas Jalan Pasir Hayam KM BDG $75 \pm 0.00$ - Cibeber KM BDG $82 \pm 0.00$.

\section{BAB II TINJAUAN PUSTAKA}

\subsection{Pengertian Jalan}

Menurut Undang-Undang No.13 Tahun 1980, Jalan adalah suatu prasarana perhubungan darat dalam bentuk apapun meliputi bagian jalan termasuk bangunan pelengkap dan perlengkapannya yang diperuntukan bagi lalu-lintas.

Jalan, menurut Undang-Undang Republik Indonesia Nomor 38 Tahun 2004 adalah prasarana transportasi darat yang meliputi segala bagian jalan, termasuk bangunan pelengkap dan perlengkapannya yang diperuntukkan bagi lalu lintas, yang berada pada permukaan tanah, di atas permukaan tanah, di bawah permukaan tanah dan/atau air, serta di atas permukaan air, kecuali jalan kereta api, jalan lori, dan jalan, kabel.

\subsection{Klasisikasi jalan}

Klasifikasi jalan atau hirarki jalan adalah pengelompokan jalan berdasarkan fungsi jalan, berdasarkan administrasi pemerintahan dan berdasarkan muatan sumbu yang menyangkut dimensi dan berat kendaraan. Penentuan klasifikasi jalan terkait dengan besarnya volume lalu lintas yang menggunakan jalan tersebut, besarnya kapasitas jalan, keekonomian dari jalan tersebut serta pembiayaan 
pembangunan dan perawatan jalan.

1. Klasifikasi berdasarkan fungsi jalan

2. Klasifikasi Jalan Menurut Sistem Jaringan Jalan

3. Klaisifikasi Jalan Menurut Adminiatrasi Pemerintah

4. Klasifikasi berdasarkan beban muatan sumbu.

\subsection{KAPASITAS JALAN DAN TINGKAT PELAYANAN}

Menurut MKJI (1997) Kapasitas adalah jumlah maksimum kendaraan atau orang yang dapat melintasi suatu titik pada lajur jalan pada periode waktu tertentu dalam kondisi jalan tertentu atau merupakan arus maksimum yang dapat dilewatkan pada suatu ruas jalan.

\section{Macam-macam Kapasitas jalan}

\section{a. Kapasitas Dasar (Basic capacity)}

Kapasitas dasar adalah jumlah kendaraan atau orang maksimum yang dapat melintas suatu penampang jalan tertentu selama satu jam pada kondisi jalan dan lalulintas yang ideal

\section{b. Kapasitas Rencana (Design Capacity)}

Kapasitas rencana adalah jumlah kendaraan atau orang maksimum yang dapat melintas suatu penampang jalan tertentu selama satu jam pada kondisi jalan dan lalu lintas yang sedang berlaku tanpa mengakibatkan kemacetan, kelambatan dan bahaya yang masih dalam batas-batas yang diinginkan

\section{c. Kapasitas yang Mungkin (Possible Capacity)}

Kapasitas yang mungkin adalah jumlah kendaraan atau orang maksimum yang dapat melintasi suatu penampang jalan tertentu selama 1 jam pada kondisi jalan dan lalu lintas yang sedang berlaku (pada saat itu). Kapasitas yang mungkin nilainya lebih kecil daripada kapasitas rencana.

\section{Tingkat Pelayanan}

Tingkat pelayanan atau "Level of Seervice" adalah tingkat pelayanan dari suatu jalan yang menggambarkan kualitas suatu jalan dan merupakan batas kondisi pengoperasian.

Tingkat pelayanan suatu jalan merupakan ukuran kualitatif yang digunakan United States Highway Capacity Manual (USHCM 1985) yang menggambarkan kondisi operasional lalu lintas dan penilaian oleh pemakai jalan.

\subsection{Perkerasan Lentur}

Pada umumnya perkerasan lentur baik digunakan untuk jalur lalu lintas dengan lalu lintas utama kendaraan penumpang, jalan perkotaan dengan sistem utilitas yang kurang baik dan terletak di bawah perkerasan jalan, untuk perkerasanbahu jalan, atau perkerasan dengan konstruksi bertahap.Sedangkan menurut peneliti perkerasan lentur (flexiblePavement) adalah suatu perkerasan jalan yang menggunakan campuran beraspal sebagai bahan pengikat pada lapis permukaan.Struktur perkerasan lentur dibangun dari beberapa lapisan yang makin ke bawah memiliki daya dukung yang semakin jelek, yaitu :

1) Lapis permukaan (surface course)

2) Lapis pondasi (base course)

3) Lapis pondasi bawah (subbase course)

4) Lapis tanah dasar (subgrade)

Keuntungan menggunakan perkerasan lentur adalah sebagai berikut :

1) Dapat digunakan pada daerah dengan perbedaan penurunan (differential settlement) terbatas.

2) Mudah diperbaiki.

3) Tambahan lapisan perkerasan dapat dilakukan kapan saja.

4) Memiliki tahanan gesek yang baik

5) Warna perkerasan memberikan kesan silau bagi pemakai jalan. 
6) Dapat dilaksanakan bertahap, terutama pada kondisi biaya pembangunan terbatas.

Kerugian menggunakan perkerasan lentur adalah :

1) Tebal total struktur perkerasan lebih tebal dari perkerasan kaku.

2) Kelenturan dan sifat kondisi berkurang seiring waktu.

3) Waktu pelayanan sampai membutuhkan pemeliharaan lebih cepat daripada perkerasan kaku.

4) Tidak baik digunakan jika sering digenangi air.

\subsection{Konstruksi Perkerasan Kaku Jalan (Rigid Pavement)}

Perkerasan beton semen semen atau perkerasan kaku (Rigid Pavement) adalah struktur yang terdiri atas pelat beton semen yang bersambung (tidak menerus) tanpa atau dengan tulangan, atau menerus dengan tulangan, terletak di atas lapis pondasi bawah atau tanah dasar, tanpa atau dengan lapis permukaan beraspal.

Perkerasan kaku pada umumnya baik digunakan untuk jalan dengan volume lalu lintas tinggi dan di dominasi oleh kendaraan berat, di sekitar pintu tol karena kendaraan berat melintas dengan kecepatan rendah, atau di daerah jalan keluar atau jalan masuk ke jalur utama jalan berkecepatan tinggi yang didominasi oleh kendaraan berat. Keuntungan menggunakan perkerasan kaku adalah sebagai berikut :

1) Umur pelayanan panjang dengan pemeliharaan yang sederhana.

2) Durabilitas baik.

3) Mampu bertahan pada banjir yang berulang, atau genangan air tanpa terjadinya kerusakan yang berarti.

Kerugian menggunakan perkerasan kaku adalah sebagai berikut :

1) Kekesatan jalan kurang baik dan mutu kekasaran permukaan dipengaruhi oleh proses pelaksanaan.
2) Memberikan kesan silau bagi pemakai jalan.

3) Membutuhkan lapisan tanah dasar yang memiliki penurunan (settlement) yang homogen agar pelat beton tidak retak. Untuk mengatasi hal ini seringkali di atas permukaan tanah dasar diberi lapis pondasi bawah sebagai pembentuk

\subsection{Rencana Anggaran Biaya}

Secara umum pengertian Rencana Anggaran Biaya (RAB) proyek adalah nilai estimasi biaya yang harus disediakan untuk pelaksaan sebuah kegiatan proyek. Namun beberapa praktisi mendefinisikan secara lebih detail, seperti :

1. Menurut Sugeng Djojowirono, 1984, Rencana Anggaran Biaya (RAB) Proyek merupakan perkiraan biaya yang diperlukan untuk setiap pekerjaan dalam suatau proyek kontruksi sehingga akan diperoleh biaya total yang diperlukan untuk menyelesaikan proyek

2. Menurut Ir.A Soedrajat Sastaadmadja, 1984 dalam bukunya "ANALISA ANGGARAN BIAYA" bahwa rencana anggaran biaya dibagi menjadi dua, yaitu rencana anggaran tereperinci dan anggaran biaya kasar

3. J.A.Mukomoko, dalam bukunya dasar penuyusunan Anggaran Biaya Bangunan, 1987 adalah perkiraan nilai uang dari suatu kegiatan ( proyek ) yang telah memperhitunkan gambar-gambar bestek serta rencana kerja, daftar uoah, daftar

\section{- Kegunaan RAB}

Sebuah pemyususnan rencana anggaran biaya proyek memiliki kegunaan, anatara lain 
1. Sebagai bahan dasar usulan pengajuan proposal agar didapatnya sejumlah alihan dana bagi sebuah pelaksaan proyek dari pemerintahan pusat ke daerha pada instansi-instansi tertentu

2. Sebagai standar harga patokan sebuah proyek yang dibuat oleh stake holder dalam bentuk owner estimate

3. Sebagai bahan pembanding harga bagi stakes holder dalam menilai tingkat kewajaran owner estimate yang dibuat oleh pihak konsultan

4. Sebagai rincian item harga penawaran yang dibuat kontraktor dalama menawar pekerjaan proyek

5. Sebagai dasar penentuan kelayakan ekonomi teknik sebuah invetasi proyek sebelum dilaksanakan pembanguannya harga bahan, buku analisa, daftar sussunan rencana biaya, seta biaya jumlah item jenis pekerjaan

\section{BAB III METODOLOGI}

\subsection{Pengumpulan Data}

Proses pengumpulan data dilakukan untuk mendapatkan bahan dalam perencanaan jalan. Pengumpulan data ini dilakukan dengan cara survey langsung lokasi perencanaan untuk mendapatkan data primer dan mendatangi instansi terkait untuk mendapatkan data sekunder mengenai jalan yang akan dibahas. Data-data yang akan dikumpulkan untuk dibahas antara lain adalah

- Data teknik jalan untuk mengetahui panjang, lebar, jenis dan kelas jalan.

- Nilai CBR tanah dasar untuk mendapatkan korelasi daya dukung tanah dasar.

- Data lalu lintas harian rencana (LHR).

- Umur Rencana

- Umur rencana.

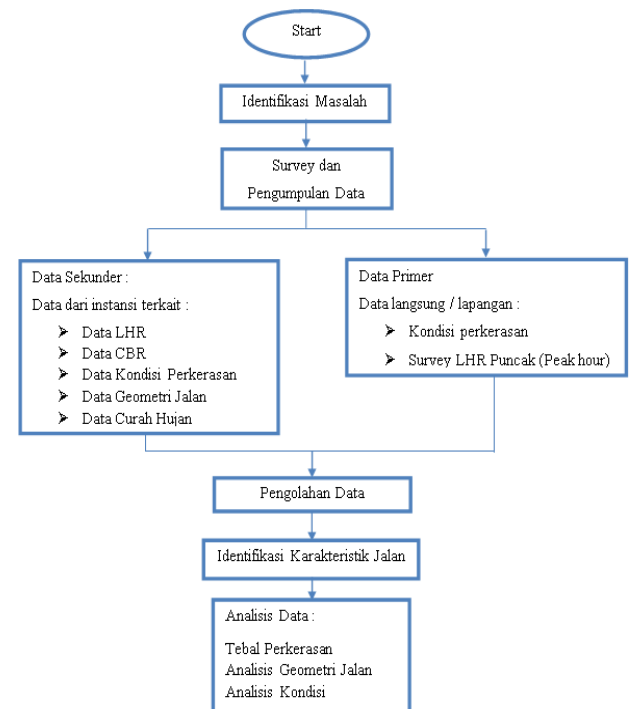

Gambar : 3.1 Flow Chart Penelitian Sumber : Rencana Penyusun

\subsection{Pengolahan data}

Proses pengumpulan data dilakukan untuk mendapatkan bahan dalam perencanaan jalan. Pengumpulan data ini dilakukan dengan cara survey langsung lokasi perencanaan untuk mendapatkan data primer dan mendatangi instansi terkait untuk mendapatkan data sekunder mengenai jalan yang akan dibahas. Data-data yang akan dikumpulkan untuk dibahas antara lain adalah :

a. Data teknik jalan untuk mengetahui panjang, lebar, jenis dan kelas jalan.

b. Nilai CBR tanah dasar untuk mendapatkan korelasi daya dukung tanah dasar.

c. Data lalu lintas harian rencana (LHR).

d. Geometrik jalan yang sudah ada

Setelah data-data di atas sudah dirasa cukup, maka akan dilakukan analisa data berdasarkan data tersebut berdasarkan standar yang ada, sehingga dapat dihasilkan hasil evaluasi mengenai perkerasan dan geometrik jalan yang diteliti dan menghasilkan desain perkerasan dan geometrik jalan yang baru dan diharapkan dapat melayani beban lalu lintas sesuai dengan umur rencana dan geometrik jalan 
yang lebih nyaman dan aman bagi pengguna jalan.

\section{BAB IV ANALISIS DATA}

\subsection{Analisa Kecepatan Arus Bebas}

Tabel 4.1 Kecepatan Arus Bebas Dasar FV0 untuk Jalan Perkotaan

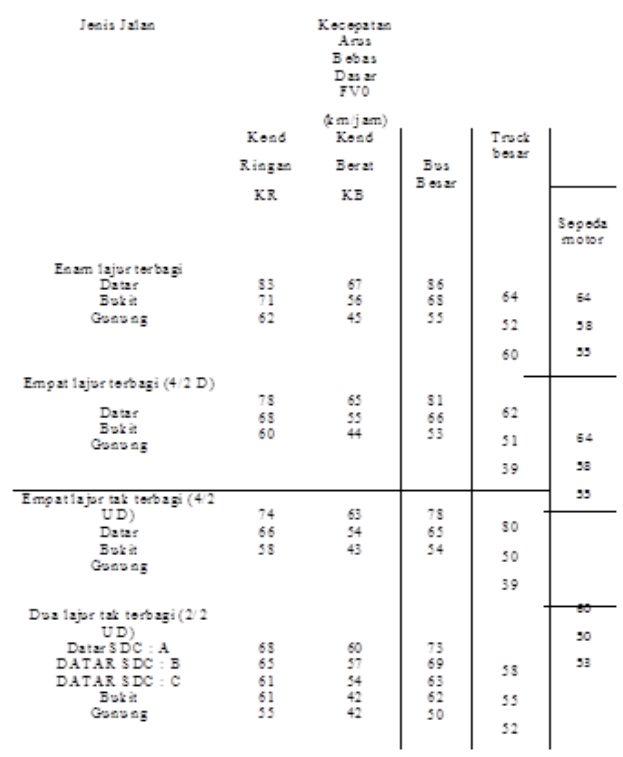

Tabel 4.2. Faktor Penyesuaian FVW untuk

Pengaruh Lebar Lajur Lalu lintas pada Kecepatan Arus Bebas Kendaraan Ringan, Jalan luar perkotaan

\begin{tabular}{|c|c|c|c|c|}
\hline \multirow[t]{2}{*}{ Tipe jalan } & \multirow{2}{*}{$\begin{array}{c}\begin{array}{c}\text { Lebar efektif } \\
\text { jalur lalu } \\
\text { lintas (W) } \\
(\mathrm{m})\end{array} \\
\end{array}$} & \multicolumn{3}{|c|}{$\mathrm{FV}_{\mathrm{w}} \quad(\mathrm{km} / \mathrm{jam})$} \\
\hline & & $\begin{array}{c}\text { Datar: SDC= } \\
A, B\end{array}$ & $\begin{array}{c}- \text { Bukit: } \mathrm{SDC}=\mathrm{A}, \mathrm{B}, \mathrm{C} \\
\text {-Datar: } \mathrm{SDC}=\mathrm{C}\end{array}$ & Gunung \\
\hline $\begin{array}{l}\text { Empat-lajur } \\
\text { dan Enam-lajur } \\
\text { terbagi }\end{array}$ & $\begin{array}{r}\text { Per lajur } \\
3,00 \\
3,25 \\
3,50 \\
3,75 \\
\end{array}$ & $\begin{array}{c}-3 \\
-1 \\
0 \\
2 \\
2 \\
\end{array}$ & $\begin{array}{c}-3 \\
-1 \\
0 \\
2 \\
2 \\
\end{array}$ & $\begin{array}{c}-2 \\
-1 \\
0 \\
2 \\
\end{array}$ \\
\hline $\begin{array}{l}\text { Empat-laju: } \\
\text { tak terbagi }\end{array}$ & $\begin{array}{r}\text { Per lajur } \\
3,00 \\
3,25 \\
3,50 \\
3,75 \\
\end{array}$ & $\begin{array}{c}-3 \\
-1 \\
0 \\
0 \\
2 \\
\end{array}$ & $\begin{array}{c}-2 \\
-1 \\
0 \\
2 \\
2\end{array}$ & $\begin{array}{c}-1 \\
-1 \\
0 \\
2 \\
\end{array}$ \\
\hline $\begin{array}{l}\text { Dua-lajur } \\
\text { tak terbagi }\end{array}$ & $\begin{array}{r}\text { Total } \\
5 \\
6 \\
7 \\
7 \\
8 \\
9 \\
10 \\
11\end{array}$ & $\begin{array}{c}-11 \\
-3 \\
0 \\
1 \\
2 \\
3 \\
3\end{array}$ & $\begin{array}{l}-9 \\
-2 \\
0 \\
1 \\
2 \\
3 \\
3\end{array}$ & $\begin{array}{l}-7 \\
-1 \\
0 \\
0 \\
1 \\
2 \\
2\end{array}$ \\
\hline
\end{tabular}

Tabel 4.3 Faktor Penyesuaian FFVSF untuk Pengaruh Hambatan Samping dan Lebar Bahu pada Kecepatan Arus Bebas

Kendaraaan Ringan untuk Jalan luar kota dengan Bahu

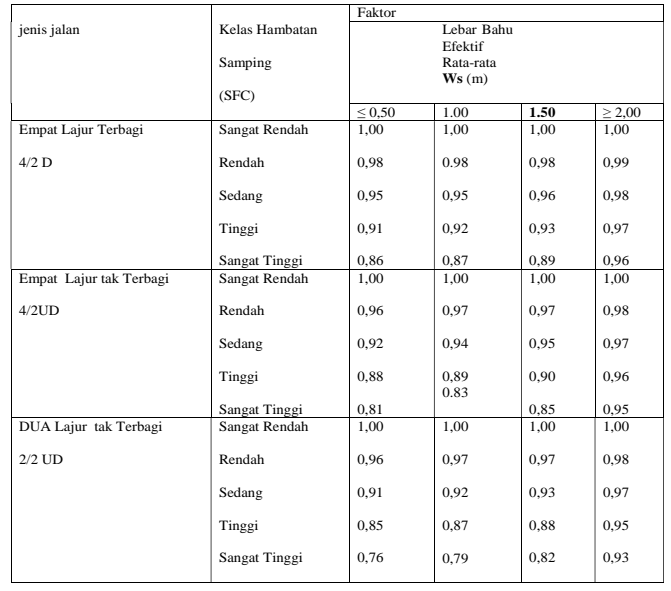

Tabel 4.4. penyuasaian akibat kelas fungsional dan guna tata lahan

\begin{tabular}{|c|c|c|c|c|c|}
\hline \multirow{2}{*}{ Tipe Jalan } & \multicolumn{5}{|c|}{ Faktor penyesuaian $\mathrm{FFV}_{\mathrm{W}}$} \\
\cline { 2 - 6 } & \multicolumn{5}{|c|}{ Pengembangan samping jalan (\%) } \\
\cline { 2 - 6 } & 0 & 25 & 50 & 75 & 100 \\
\hline Empat-lajur terbagi & & & & & \\
Arteri & 1,00 & 0,99 & 0,98 & 0,96 & 0,95 \\
Kolektor & 0,99 & 0,98 & 0,97 & 0,95 & 0,94 \\
Lokal & 0,98 & 0,97 & 0,96 & 0,94 & 0,93 \\
& & & & & \\
Empat-lajur tak-terbagi: & & & & & \\
Arteri & 1,00 & 0,99 & 0,97 & 0,96 & 0,945 \\
Kolektor & 0,97 & 0,96 & 0,94 & 0,93 & 0,915 \\
Lokal & 0,95 & 0,94 & 0,92 & 0,91 & 0,895 \\
& & & & & \\
Dua-lajur tak-terbagi & & & & & \\
Arteri & 1,00 & 0,98 & 0,97 & 0,96 & 0,94 \\
Kolektor & 0,94 & 0,93 & 0,91 & 0,90 & 0,88 \\
Lokal & 0,90 & 0,88 & 0,87 & 0,86 & 0,84 \\
\hline
\end{tabular}

Dalam perhitungan arus lalu lintas ringan jalan Raya Pasir Hayam KM BDG $75 \pm 0.00$ - Cibeber KM BDG $82 \pm 0.00$

a. Kecepatan arus bebas dasar $61 \mathrm{~km} / \mathrm{jam}$ (berdasarkan tabel 4.1 MKJI)

b. Faktor Penyesuaian FVW untuk Pengaruh Lebar Lajur Lalu lintas pada

Kecepatan Arus Bebas Kendaraan Ringan, Jalan Perkotaan didapatkan nilai 1 (berdasarkan tabel 4,2)

c. Faktor Penyesuaian FFVSF untuk Pengaruh Hambatan Samping dan Lebar Bahu pada Kecepatan Arus Bebas Kendaraaan Ringan untuk Jalan Perkotaan dengan Bahu .pada ruas jalan ringan Raya Cianjur KM BDG $75 \pm 0.00$

- Cibeber KM BDG $81 \pm 0.00$ didapatkan lebar bahu sebesar 1,00 meter dan jalan jalur tak berbagi (2/2 UD ) dan hambatan samping sedang hambatannya 
kersn terkadang ada banyak orang yang keluar masuk gang, sekolah, dan minimarket maka dapat nilai 0,85 (tabel 4.3 MKJI)

d. Faktor Penyesuaian kelas fungsi dan tata guna lahan FFVRC pada Kecepatan Arus Bebas untuk Jalan luar kota maka didapat nilai 0,91 ( berdasarkan tabel 4.4 dari mata kuliah rekayasa lalu lintas

Beradasarkan data-data tersebut maka dapat dihitung dengan menggunakan rumus sebagai berikut :

FV $=($ FV0 + FVw $) \times$ FFVSF $x$ FFVRc $(\mathrm{km} / \mathrm{jam}) \ldots . .(1)$

$\mathrm{FV}=(61+1) \times 0,85 \times 0,91$

$\mathrm{FV}=47,1835 \mathrm{~km} / \mathrm{jam}$

Dari perhitungan tersebut didapat hasil FV $47,1835=47 \mathrm{KM} / \mathrm{JAM}$

\subsection{Kapasitas Jalan}

Tabel 4.5. Kapasitas Dasar C0 untuk Jalan Perkotaan

\begin{tabular}{|l|l|l|}
\hline Jenis Jalan & $\begin{array}{l}\text { Kapasitas } \\
\text { Dasar C0 } \\
\text { (smp/jam) }\end{array}$ & Keterangan \\
\hline $\begin{array}{l}\text { Empat lajur } \\
\text { terbagi (4/2 } \\
\text { D) }\end{array}$ & $\begin{array}{l}1900 \\
\text { Darat }\end{array}$ & Per lajur \\
$\begin{array}{l}\text { Bukit } \\
\text { Gunung }\end{array}$ & 1800 & \\
\hline $\begin{array}{l}\text { Empat lajur } \\
\text { tak terbagi } \\
\text { (4/2 UD) }\end{array}$ & 1700 & \\
$\begin{array}{l}\text { Darat } \\
\text { Bukit }\end{array}$ & 1650 & Per lajur \\
Gunung & 1600 & \\
\hline $\begin{array}{l}\text { Dua lajur } \\
\text { tak terbagi } \\
\text { (2/2 UD) }\end{array}$ & 3100 & \\
$\begin{array}{l}\text { Darat } \\
\text { Bukit } \\
\text { Gunung }\end{array}$ & 3000 & \\
\hline
\end{tabular}

Tabel 4.6. Faktor Penyesuaian Distribusi Arah FCSP untuk Jalan
Luar kota (Khusus untuk Jalan Tidak Terbagi

\begin{tabular}{|l|l|l|l|l|l|l|}
\hline $\begin{array}{l}\text { Distrib } \\
\text { usi } \\
\begin{array}{l}\text { Arah } \\
\%\end{array}\end{array}$ & $\begin{array}{l}50 \\
-\end{array}$ & $\begin{array}{l}55 \\
-\end{array}$ & $\begin{array}{l}60 \\
-\end{array}$ & 65 & 70 \\
\hline FCSP & $\begin{array}{l}\text { Dua } \\
\text { laju } \\
\text { r 2/2 }\end{array}$ & $\begin{array}{l}1,0 \\
0\end{array}$ & 0,9 & 0,9 & 0,9 & 0,8 \\
& $\begin{array}{l}\text { emp } \\
\text { at } \\
\text { laju } \\
\text { r 4/2 }\end{array}$ & $\begin{array}{l}1,0 \\
0\end{array}$ & $\begin{array}{l}0,9 \\
8\end{array}$ & $\begin{array}{l}0,9 \\
5\end{array}$ & 0,9 & 0,9 \\
\hline
\end{tabular}

Tabel 4.7. Faktor Penyesuaian FCW untuk Lebar Lajur Lalu lintas pada Kapasitas Jalan luar kota

\begin{tabular}{|l|l|l|}
\hline Jenis Jalan & $\begin{array}{l}\text { Lebar Jalur } \\
\text { Lalu lintas } \\
\text { Efektif } \\
\text { WC (meter) }\end{array}$ & \\
\hline $\begin{array}{l}\text { Empat lajur } \\
\text { terbagi (4/2 }\end{array}$ & Per Lajur \\
D) & 3,00 & 0,91 \\
Atau sau & 3,25 & 0,96 \\
Jalan satu & 3,50 & 1,00 \\
arah & 3,75 & 1,03 \\
\hline Empat lajur & Per Lajur & \\
tak terbagi & 3,00 & 0,91 \\
(4/2 UD) & 3,25 & 0,96 \\
& 3,50 & 1,00 \\
& 3,75 & 1,03 \\
& & \\
\hline Dua lajur tak & Total & 0,69 \\
terbagi & 5 & 0,91 \\
(2/2 UD) & 7 & 1,00 \\
& 8 & 1,08 \\
& 8 & 1,15 \\
& 9 & 1,21 \\
& 10 & 1,27 \\
\hline
\end{tabular}

Dalam perencanaan kapasitas jalan Cibeber KM BDG $75 \pm 0.00-$ KM BDG $81 \pm 0.00$ didapat data sebagai berikut :

1. kapasitas dasar (smp/jam) ( co) dengan jenis jalan 2/2 UD 2jalur tanpa berbagai total dua arah maka didapat niali 3100 (menggunakan tabel 4,5 dari MKJI) 
2. FCsp faktor penyesuaian distribusi arah jalan tak berbagi dan persentasi 50-50 didapat nilai 1,00 (menggunakan tabel 4,6 mkji)

3. Faktor Penyesuaian FCW untuk Lebar Lajur Lalu lintas pada Kapasitas

Jalan Perkotaan dengan jenis lajur $2 / 2$ UD tak berbagi dan total lebar jalur 8 meter maka didapat nilai 1,08 (menggunakan tabel 5,7 MKJI )

4. Faktor Penyesuaian FCSF untuk Pengaruh Hambatan Samping dan Lebar Bahu pada Kecepatan Arus Bebas Kendaraaan Ringan untuk Jalan Perkotaan dengan Bahu .pada ruas jalan Jalan Raya Cianjur KM BDG $75 \pm 0.00$ - Cibeber KM BDG $81 \pm 0.00$ didapatkan lebar bahu sebesar 1,00 meter dan jalan jalur tak berbagi (2/2 UD ) dan hambatan samping sedang hambatannya kersn terkadang ada banyak orang yang keluar masuk gang, sekolah, dan minimarket maka dapat nilai 0,87 (tabel 4.3 dari MKJI )

Berdasarkan data-data tersebut, dapat dihitung dengan menggunaka rumus

$\mathrm{C}=\mathrm{C} 0 \times \mathrm{FCSP} \times \mathrm{FCw} \times \mathrm{FCSF}(\mathrm{smp} / \mathrm{jam})$

$\mathrm{C}=3100 \times 1 \times 1,08 \times 0,87$

$\mathrm{C}=2912,76$

Dari perhitungan kapasitas Jalan Pasir Hayam KM BDG $75 \pm 0.00$ - Cibeber KM BDG $82 \pm 0.00$ tersebut didapat nilai $\mathrm{C}=$ 2912,76 dan nilai Co $=2900$ maka tidak diperlukan pelebaran jalan karena kapsitas masih memenuhi .

\subsection{Derajat Kejenuhan}

Derajat kejenuhan didefinisikan sebagai rasio lalu lintas Q terhadap kapasitas C digunakan sebagai faktor utama dalam tingkat kinerja segmen jalan. Nilai DS menunjukan apakah segmen jalan tersebut mempunyai masalah kapasitas atau tidak.

a. LHRT (Kend/hari) pada tahun $2016=$ 22449

b. faktor $-\mathrm{k}(\mathrm{LHRT}), \mathrm{K}=0,11$

c. Nilai SP/100 dari arah 50/50 yaitu 1 d. Maka perhitungan arus jam perencana Qdh = LHRT $\times$ K $\times$ SP/100 Qdh $=22449 \times 0,11 \times 1=2469,39$

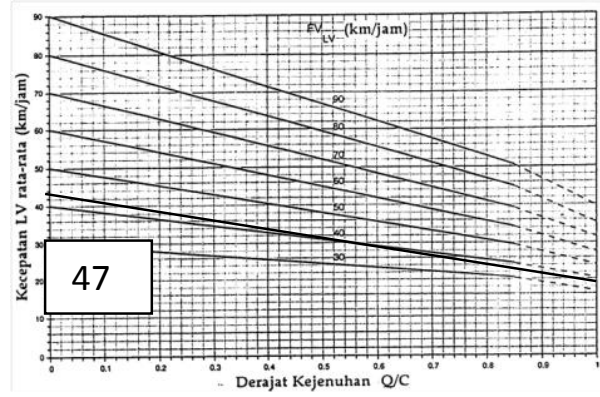

\subsection{Pengolahan Data Volume Kendaraan}

Berdasarkan data hasil survey kendaraan yang dilakukan oleh dinas Bina Mrga Provinsi Jawa Barat pada tahun 2015, maka didapat volume lalu lintas hariaan sebagai berikut

Data perkerasan jalan yang sudah ada :

Tabel 4.8 Data Perkerasan

\begin{tabular}{|l|l|l|}
\hline Laston ACWC & $10 \mathrm{Cm}$ & Sisa 60\% \\
\hline $\begin{array}{l}\text { Batu pecah ( } \\
\text { CBR 80\%) }\end{array}$ & $20 \mathrm{Cm}$ & Sisa 50\% \\
\hline $\begin{array}{l}\text { LPB sirtu } \\
\text { CBR 50\%) }\end{array}$ & $(10 \mathrm{Cm}$ & Sisa 100\% \\
\hline
\end{tabular}

Sumber : Data diperoleh dari dinas binamarga provinsi

Tabel 4.9 data survey lalu lintas arah tahun 2015

\begin{tabular}{|l|l|l|l|}
\hline $\begin{array}{l}\text { Nama } \\
\text { kendara } \\
\text { an }\end{array}$ & $\begin{array}{l}\text { GOLONG } \\
\text { AN }\end{array}$ & \multicolumn{2}{|l|}{$\begin{array}{l}\text { Banyak } \\
\text { kendaraan }\end{array}$} \\
\cline { 2 - 4 } & $\begin{array}{l}\text { Cianj } \\
\text { ur- } \\
\text { cibebe } \\
\text { r }\end{array}$ & $\begin{array}{l}\text { Cibeb } \\
\text { er- } \\
\text { cianur }\end{array}$ \\
\hline $\begin{array}{l}\text { Sepeda } \\
\text { motor, } \\
\text { sekunde } \\
\text { r dan } \\
\text { kendara } \\
\text { an roda } \\
\text { tiga }\end{array}$ & 1 & 21990 & 7330 \\
\hline $\begin{array}{l}\text { Sedan, } \\
\text { jeep dan }\end{array}$ & 2 & 4038 & 2019 \\
$\begin{array}{l}\text { Station } \\
\text { Wagon }\end{array}$ & & & \\
\hline $\begin{array}{l}\text { Pick up, } \\
\text { Suburba }\end{array}$ & 3 & 4720 & 2360 \\
\hline
\end{tabular}




\begin{tabular}{|l|l|l|l|}
\hline $\begin{array}{l}\mathrm{n} \\
\text { Combi }\end{array}$ & & & \\
\hline $\begin{array}{l}\text { Pick up } \\
\text { dan } \\
\text { mobil } \\
\text { hataran }\end{array}$ & 4 & 7764 & 5176 \\
\hline $\begin{array}{l}\text { Bus } \\
\text { kecil }\end{array}$ & $5 \mathrm{a}$ & 168 & 112 \\
\hline $\begin{array}{l}\text { Bus } \\
\text { besar }\end{array}$ & $5 \mathrm{~b}$ & 0 & 0 \\
\hline $\begin{array}{l}\text { Truck 2 } \\
\text { sumbu } \\
\text { (small } \\
\text { large) }\end{array}$ & $6 \mathrm{a}$ & 2492 & 1780 \\
\hline $\begin{array}{l}\text { Truck 2 } \\
\text { sumbu } \\
\text { (large } \\
\text { truck) }\end{array}$ & $6 \mathrm{~b}$ & 67 & 48 \\
\hline $\begin{array}{l}\text { Truck 3 } \\
\text { sumbu }\end{array}$ & $7 \mathrm{a}$ & 0 & 0 \\
\hline $\begin{array}{l}\text { Truck } \\
\text { gandeng }\end{array}$ & $7 \mathrm{~b}$ & 0 & 0 \\
\hline $\begin{array}{l}\text { Kendara } \\
\text { an tidak } \\
\text { bermoto } \\
\mathrm{r}\end{array}$ & 8 & 402 & 0 \\
\hline
\end{tabular}

Sumber $=$ Dinas Lalu Lintas dan Angkutan Jalan

Tabel 4.10 komposisi jenis kendaraan (kend/hari/2arah) tahun 2016

\begin{tabular}{|l|l|}
\hline Nama kendaraan & Jumlah kendaraan \\
\hline $\begin{array}{l}\text { Sepeda motor, sekunder } \\
\text { dan kendaraan roda tiga }\end{array}$ & 10216 \\
\hline $\begin{array}{l}\text { Sedan, jeep dan Station } \\
\text { Wagon }\end{array}$ & 9056 \\
\hline Bus keci & 195 \\
\hline Bus besar & 0 \\
\hline Truck kecil & 2906 \\
\hline Truk besar & 76 \\
\hline Truck 3 sumbu & 0 \\
\hline Truck gandeng & 0 \\
\hline & \\
\hline
\end{tabular}

Setelah Lalu lintas harian rata-rata pada awal rencana (LHRp), maka dihitung pula lalu lintas harian Rata-rata pada akhir tahun rencana (LHRa) denggan menggunakan rumus $(1+1)$
Tabel 4.11 komposisi jenis kendaraan tahun 2025

\begin{tabular}{|c|c|}
\hline & \\
Nama kendara & Jumlah kendaraan \\
\hline $\begin{array}{c}\text { Sepeda motor, sekunder } \\
\text { dan kendaraan roda tiga }\end{array}$ & 22056 \\
\hline $\begin{array}{c}\text { Sedan, jeep dan Station } \\
\text { Wagon }\end{array}$ & 19551 \\
\hline Bus keci & 421 \\
\hline Bus besar & 0 \\
\hline Truck kecil & 6273 \\
\hline Truk besar & 167 \\
\hline Truck 3 sumbu & 0 \\
\hline Truck gandeng & 0 \\
\hline
\end{tabular}

Setelah lalu lintas harian rata-rata pada awal rencana (LHRp) dan (LHRa) didsapat, kemudian dicari nilai angka ekivalen beban sumbu kendaraan

Tabel 4.12 Nilai E

\begin{tabular}{|c|c|c|c|c|}
\hline \multirow{2}{*}{$\begin{array}{l}\text { Jenis } \\
\text { kendara } \\
\text { an }\end{array}$} & \multirow{2}{*}{$\begin{array}{l}\text { Berat } \\
\text { maksim } \\
\text { um } \\
((\text { ton })\end{array}$} & \multicolumn{2}{|l|}{ Roda } & \multirow{2}{*}{$\begin{array}{l}\text { Nilai } \\
\text { E }\end{array}$} \\
\hline & & $\begin{array}{l}\text { Depa } \\
n\end{array}$ & $\begin{array}{l}\text { belaka } \\
\text { ng }\end{array}$ & \\
\hline $\begin{array}{l}\text { Kendara } \\
\text { an } \\
\text { ringan }\end{array}$ & 2 & $\begin{array}{l}0.00 \\
02\end{array}$ & 0.0002 & $\begin{array}{l}0.00 \\
04\end{array}$ \\
\hline Pick up & 4 & $\begin{array}{l}0.00 \\
07\end{array}$ & 0.011 & $\begin{array}{l}0.01 \\
17\end{array}$ \\
\hline $\begin{array}{l}\text { Bus } \\
\text { kecil }\end{array}$ & 9 & $\begin{array}{l}0.01 \\
97\end{array}$ & 0.2808 & $\begin{array}{l}0.30 \\
05\end{array}$ \\
\hline $\begin{array}{l}\text { Truck } \\
\text { kecil }\end{array}$ & 18.3 & $\begin{array}{l}0.01 \\
43\end{array}$ & 0.2031 & $\begin{array}{l}0.21 \\
74\end{array}$ \\
\hline $\begin{array}{l}\text { Truk } \\
\text { besar }\end{array}$ & 18.2 & $\begin{array}{l}0.33 \\
07\end{array}$ & 4.6957 & $\begin{array}{l}5.02 \\
64\end{array}$ \\
\hline
\end{tabular}

Setelah menghitung ekivalen selanjutnya menghitung lintas ekivalen permulaan (LEP), LIntas ekivalen akhir (LEA), lintas ekivalen tengah (LET) dan lintas eivalen rencana (LER) 
Tabel 4.13 Nilai LEP

\begin{tabular}{|c|c|c|c|c|c|}
\hline $\begin{array}{l}\text { Jenis } \\
\text { kendar } \\
\text { aan }\end{array}$ & $\begin{array}{l}\text { Berat } \\
\text { maksi } \\
\text { mum } \\
\text { (ton) }\end{array}$ & $\begin{array}{l}\mathrm{Ni} \\
\text { lai } \\
\mathrm{C}\end{array}$ & $\begin{array}{l}\mathrm{LH} \\
\mathrm{Rp}\end{array}$ & $\mathrm{E}$ & LEP \\
\hline $\begin{array}{l}\text { Kenda } \\
\text { raan } \\
\text { ringan }\end{array}$ & 2 & 0.5 & $\begin{array}{l}102 \\
16 \\
\end{array}$ & $\begin{array}{l}0.00 \\
04\end{array}$ & 2.043 \\
\hline $\begin{array}{l}\text { Pick } \\
\text { up } \\
\text { combi }\end{array}$ & 4 & 0.5 & $\begin{array}{l}905 \\
6\end{array}$ & $\begin{array}{l}0.01 \\
17\end{array}$ & $\begin{array}{l}52,97 \\
76\end{array}$ \\
\hline $\begin{array}{l}\text { Bus } \\
\text { kecil }\end{array}$ & 9 & 0.5 & 195 & $\begin{array}{l}0.30 \\
05\end{array}$ & $\begin{array}{l}29.29 \\
875 \\
\end{array}$ \\
\hline $\begin{array}{l}\text { Truck } \\
\text { kecil }\end{array}$ & 8.3 & 0.5 & $\begin{array}{l}290 \\
6 \\
\end{array}$ & $\begin{array}{l}0.21 \\
74 \\
\end{array}$ & $\begin{array}{l}315.8 \\
822 \\
\end{array}$ \\
\hline $\begin{array}{l}\text { Truck } \\
\text { besar }\end{array}$ & 18.2 & 0.5 & 76 & $\begin{array}{l}5.02 \\
64 \\
\end{array}$ & $\begin{array}{l}191.0 \\
01 \\
\end{array}$ \\
\hline \multicolumn{5}{|c|}{$\begin{array}{l}\text { Jum } \\
\text { lah }\end{array}$} & $\begin{array}{l}591.5 \\
535\end{array}$ \\
\hline
\end{tabular}

Tabel 4.14 Nilai LEA

\begin{tabular}{|l|l|l|l|l|l|}
\hline $\begin{array}{l}\text { Jenis } \\
\text { kenda } \\
\text { raan }\end{array}$ & $\begin{array}{l}\text { Berat } \\
\text { maksi } \\
\text { mum } \\
\text { (ton) }\end{array}$ & $\begin{array}{l}\text { Ni } \\
\text { lai } \\
\text { C }\end{array}$ & $\begin{array}{l}\text { LH } \\
\text { Ra }\end{array}$ & E & LEA \\
\hline $\begin{array}{l}\text { Kenda } \\
\text { raan } \\
\text { ringan }\end{array}$ & 2 & $\begin{array}{l}0 . \\
5\end{array}$ & $\begin{array}{l}220 \\
56\end{array}$ & $\begin{array}{l}0.0 \\
004\end{array}$ & $\begin{array}{l}4.411 \\
2\end{array}$ \\
\hline $\begin{array}{l}\text { Pick } \\
\text { up } \\
\text { combi }\end{array}$ & 4 & 0. & $\begin{array}{l}195 \\
51\end{array}$ & $\begin{array}{l}0.0 \\
117\end{array}$ & $\begin{array}{l}114.3 \\
7335\end{array}$ \\
\hline $\begin{array}{l}\text { Bus } \\
\text { kecil }\end{array}$ & 9 & 0. & 421 & 0.3 & 63.25 \\
\hline $\begin{array}{l}\text { Truck } \\
\text { kecil }\end{array}$ & 8.3 & 0. & $\begin{array}{l}627 \\
5\end{array}$ & $\begin{array}{l}0.2 \\
174\end{array}$ & $\begin{array}{l}682.1 \\
88\end{array}$ \\
\hline $\begin{array}{l}\text { Truck } \\
\text { besar }\end{array}$ & 18.2 & 0. & 167 & 5.0 & $\begin{array}{l}419.7 \\
5\end{array}$ \\
\hline & & 5 & & 264 & 044 \\
\hline
\end{tabular}

TABEL 4.15 Hasil LET

\begin{tabular}{|l|l|l|}
\hline LET & $=$ & $0,5 \times($ LEP+LEA $)$ \\
\hline LET & $=$ & $\begin{array}{l}0.5 \\
+1283.9322)\end{array}$ \\
\hline LET & $=$ & 937.7285 \\
\hline
\end{tabular}

TABEL 4.16 Hasil LER

\begin{tabular}{|l|l|ll|}
\hline LER & $=$ & LET $\times$ UR/10 \\
\hline LER & $=$ & $937.7285 \quad \mathrm{x}$ \\
& & $10 / 10$ \\
\hline
\end{tabular}

\begin{tabular}{|l|l|l|}
\hline LER & $=$ & 937.7285 \\
\hline
\end{tabular}

\subsection{Menentukan Nilai CBR dan Daya} Dukung tanah (DDT)

Berdasarkan data-data yang diperoleh dari dinas bina marga provinsi jawa barat, ahrag CBR jalan raya CIbeber KM BDG 75 $\pm 0.00-$ KM BDG $82 \pm 0.00$. CBR rata-rata tanah sebagai berikut

Tabel 4.17 Nilai data CBR penelitian

\begin{tabular}{|l|l|}
\hline STA & CBR \% \\
\hline $75 \pm 0.00$ & 5.30 \\
\hline $76 \pm 0.00$ & 6.40 \\
\hline $77 \pm 0.00$ & 6.80 \\
\hline $78 \pm 00$ & 7.00 \\
\hline $79 \pm 0.00$ & 7.20 \\
\hline $80 \pm 0.00$ & 6.90 \\
\hline $81 \pm 0.00$ & 6.50 \\
\hline $82 \pm 0.00$ & 6.60 \\
\hline
\end{tabular}

Sumber : data bina marga provinsi

Tabel 4.18 menentukan tabel dengan cara grafis

\begin{tabular}{|c|c|c|}
\hline CBR & $\begin{array}{l}\text { Jumlah } \\
\text { yang sama }\end{array}$ & $\begin{array}{l}\text { Persen }(\%) \\
\text { yang sama }\end{array}$ \\
\hline 5.3 & 71 & 100 \\
\hline 6.4 & 67 & 94.3662 \\
\hline 6.5 & 58 & 81.6901 \\
\hline 6.6 & 48 & 67.6056 \\
\hline 6.8 & 33 & 46.4789 \\
\hline 6.9 & 30 & 42.2535 \\
\hline 7 & 27 & 38.0282 \\
\hline 7.2 & 26 & 36.61 \\
\hline
\end{tabular}




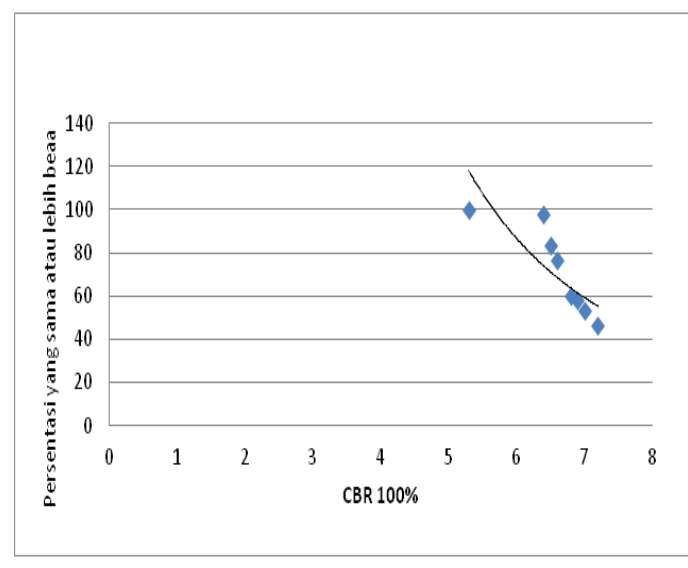

\subsubsection{Menetukan Nilai Faktor Regional}

Berdasarkan data penelitian yang diperoleh didapatkan persentasi kendaaran besar (>13 ton ) sebesar $14.17 \%,(<30 \%)$ curah hujan daerah kabupaten cianjur berkisar 1750 $\mathrm{mm} / \mathrm{th}$ ( $<900 \mathrm{~mm} / \mathrm{th}$ ) dari daftar 4, "tata cara perencanaan tabel perkerasan lentur jalan raya metode komponen SNI - 1732 -1989 $\mathrm{F}$, maka nilai $\mathrm{FR}=1.5$

\subsubsection{Menentukan indeks permukaan}

Indek permukaan ini menyatakan nikai dari keratin atau kehalusan, serta kekokohan permukaan yang bertahan tingkat pelayanan bagi lalu lintas. Berdasarkan daftar 4, "tata cara perencanaan tabel perkerasan lentur jalan raya metode komponen SNI - 1732 1989 -F , memiliki IPo berkisar antara 3,93,5 maka dipilih sebesar 3,8

\subsubsection{Menentukan koefesien kekuatan} relative (a)

Nilai koefesien relative (a) diambil dari dafttar 7, "tata cara perencanaan tabel perkerasan lentur jalan raya metode komponen SNI - 1732 -1989-F

Tabel 4.17 kekuatan relative (a)

\begin{tabular}{|l|l|}
\hline Jenis lapisan & $\begin{array}{l}\text { Koefesien kekuatan } \\
\text { relative (a) }\end{array}$ \\
\hline Laston & 0,40 \\
\hline $\begin{array}{l}\text { Batu pecah CBR } \\
80 \%\end{array}$ & 0.13 \\
\hline Sirtu & 0.12 \\
\hline
\end{tabular}

\subsection{5 menentukan indeks tebal perkerasan} ( ITP)

Menggunakan, "tata cara perencanaan tabel perkerasan lentur jalan raya metode komponen SNI - 1732 -1989-F didapat 10.4 $\mathrm{cm}$

\subsection{Menetapkan Tebal lapis tambahan}

Tabel 18 Umur rencana 10 tahun

\begin{tabular}{|l|l|}
\hline $\begin{array}{l}\text { Kekuatan jalan } \\
\text { lama }\end{array}$ & \\
\hline $\begin{array}{l}\text { Laston a1 }=0.40 \\
\text { tebal } 10 \mathrm{~cm}\end{array}$ & $=60 \% \times 0.40 \times 10=2.4$ \\
\hline $\begin{array}{l}\text { Batu pecah CBR } \\
80 \% \text { a2 }=0.13 \\
\text { tebal } 20 \mathrm{~cm}\end{array}$ & \\
\hline $\begin{array}{l}\text { Sirtu a }=0.12 \\
\text { CBR } 100 \% \text { tebal }\end{array}$ & $100 \% \times 0.12 \times 10=1.2$ \\
$=10$ & \\
\hline ITP yang ada & 4.9 \\
\hline
\end{tabular}

jadi jalan tambahan atau overlay

- $\quad$ ITP $=$ ITP10 - ITPada

- $\quad$ ITP $=10.4-4.9=5.5$

- $\quad \mathrm{ITP}=\mathrm{a} 0 \mathrm{D} 0$

- $\mathrm{D} 0=13.75 \mathrm{Cm}$

$5.5=0.40 \mathrm{D} 0$

$\mathrm{D} 0=13.75 \mathrm{Cm}$

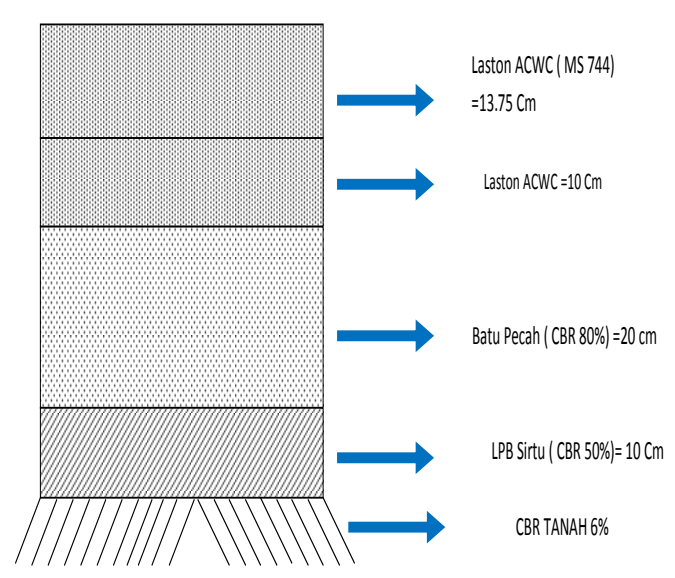

\subsection{Rencana Anggaran Biaya}

Dari perhitungan Rencana Anggaran Biaya penambahan jalan atau overlay dari ruas jalan Ruas jalan Pasir Hayam - Cibeber Kecamatan Cibeber KabupatenCianjur 
(Km. Bdg 75 - Km. Bdg 82) dengan data yang nyaitu panjang $7 \mathrm{~km}$, lebar jalan 8 meter, dengan tebal $13.75 \mathrm{~cm}$.

Maka dari hasil perhitungan Rencana Anggaran Biaya (RAB) pada penambahan jalan pada Ruas jalan Pasir Hayam - Cibeber Kecamatan Cibeber KabupatenCianjur (Km. Bdg $75-\mathbf{K m}$. Bdg 82) sebesar Rp $12,496,385,293.79$

\section{BAB V PENUTUP}

\subsection{KESIMPULAN}

Dari pengumpulan data hingga analisa data yang telah di lakukan dalam Tugas Akhir ini, di dapatkan beberapa kesimpulan berdasarkan hasil analisa data dan evaluasi perencanaan dalam Tugas Akhir ini, diantaranya

1. Dari perhitungan kapasitas Jalan Pasir Hayam KM BDG $75 \pm 0.00$ - Cibeber KM BDG $82 \pm 0.00$ tersebut didapat nilai $\mathrm{C}=2912,76$

2. Berdarkan dari analisi kapasitas dasar dan kapasitas jalan pada ruas jalan Pasir Hayam KM BDG $75 \pm 0.00$ - Cibeber KM BDG $82 \pm 0.00$ masih cukup maka tidak diperlukan pelebaran jalan

3. Berdasarkan hasil perhitungan analisa penambaham jalan atau overlay pada jalan KM BDG $75 \pm 0.00$ - Cibeber KM BDG $82 \pm 0.00$ didapat penambahan jalan atau overlay setinggi $13.75 \mathrm{~cm}$ menggunakan laston (MS 744)

4. Maka dari hasil perhitungan Rencana Anggaran Biaya (RAB) pada penambahan jalan pada Ruas jalan Pasir Hayam - Cibeber Kecamatan Cibeber KabupatenCianjur $(\mathbf{K m}$. Bdg 75 - Km. Bdg 82) sebesar Rp 12.496.385.293

\subsection{Saran}

Berdasarkan kesimpulan yang diambil dari analisa yang telah di lakukan padaTugas akhir ini, untuk dapat di hasilkan jalan yang sesuai dengan umur rencana, aman, dan nyaman, penulis memberikan beberapa saran sebagai berikut :

1. Pada ruas jalan Pasir Hayam - Cibbeber Kecamatan Cibeber Kabupaten Cianjur $\mathrm{Km}$. Bdg 75 s/d 82 diharuskan ada tempat parker sehingga tidak ada mobil yang parker di ruas jalan

2. Muatan yang diangkut oleh mobil niaga yang melintasi ruas jalan Pasir Hayam Cibbeber Kecamatan Cibeber Kabupaten Cianjur Km. Bdg 75 s/d 82 harus sesuai dengan muatan yang di ijinkan untuk ruas jalani ni, sehingga jalan tidak mengalami kerusakan sebelum mencapai umur rencana perkerasan jalan.

3. Instansi terkait (Dinas Perhubungan dan kepolisian), seharusnya sering melakukan penertiban berupa operasi rutin untuk mengatasi mobil niaga yang memuat muatan berlebih. Apabila mobil niaga sudah melakukan pemuatan muatan yang sesuai dengan muatan ijin, maka perkerasan jalan dapat terhindar dari kerusakan struktur perkerasan sebelum umur rencana.

4. Perlu adanya rambu - rambu batas maksimal berat muatan, perlu di adakannya penerangan.

5. Mobil niaga (dalam hal ini truck bermuatan pasir) seharusnya memuat pasir dengan tinggi yang tidak melebihi dari tinggi bak truck. Hal ini dapat mengakibatkan ketidak stabilan truck pada saat melewati tanjakan atau turunan, selain hal itu struktur perkerasan jalan dapat mengalami kerusakan lebih cepat daripada umur rencana jalan.

\section{DAFTAR PUSTAKA}

Dewan Standardisasi Nasiaonal Perencanaan Kota MKJI 1997 
Dewan Standardisasi Nasional, Tata Cara Perencanaan Tebal Perkerasan Lentur Jalan Raya dengan Metode Analisa Komponen, SNI 1732-1989-F, 1987

Dewan Standardisasi Nasiaonal Perencanaan Kota MKJI 1997

Dewan Standardisasi Nasional, Tata Cara Perencanaan Tebal Perkerasan Lentur Jalan Raya dengan Metode Analisa Komponen, SNI 1732-1989-F, 1987

Edward K. Morlok dan Johan K. Hainim, Pengantar Teknik \& Perencanaan Transportasi (terjemahan), Penertbit Erlangga, Jakarta, 1984 http://lamongankab.go.id/instansi/dishub/20 14/05/13/jenis-klasifikasi-jalan/ http://www.ilmusipil.com/klasifikasi-jalanmenurut-fungsi

https://blackborrot.wordpress.com/2012/10/0 7/klasifikasi-jalan/

Ilham, Diktat Kuliah Perencangan Perkerasan Jalan.

Ilham, Diktat Kuliah Rekayasa Transportasi I.

Silvia Sukirman, Perkerasan Lentur Jalan Raya, Penerbit Nova, Bandung, tanpa tahun 